\title{
RAPIDLY GROWING, ACID FAST BACTERIA ${ }^{1}$
}

\section{SPecies' Description of Mycobacterium fortuitum CRuz}

\author{
RUTH E. GORDON AND MILDRED M. SMITH \\ Institute of Microbiology, Rutgers University, the State University of New Jersey, New Brunswick, \\ New Jersey
}

Received for publication October 13, 1954

The taxonomic study of the acid fast bacteria capable of comparatively rapid growth on ordinary media, first reported in 1953 by Gordon and Smith, has been continued. Additional strains have been examined and other tests applied to all the strains. A few supplementary characteristics of the two previously delineated species, Mycobacterium phlei Lehmann and Neumann and Mycobacterium smegmatis (Trevisan) Lehmann and Neumann, are presented, and the strains newly assigned to these species are listed.

As the work progressed, a third group of strains emerged. The strains of this taxon seemed closely related to each other and sufficiently distinct from the other strains of the collection to warrant their separation into a species. A description of this third species, Mycobacterium fortuitum Cruz, is given and compared with those of $M$. phlei and $M$. smegmatis.

\section{MATERIALS AND METHODS}

In addition to the observations and tests used by Gordon and Smith (1953), the following ones were employed:

Decomposition of tyrosine. The cultures were streaked on plates of tyrosine agar and examined after 14 and 21 days' incubation at $28 \mathrm{C}$ for the disappearance of the tyrosine crystals underneath and around the growth. The agar contained peptone, $5 \mathrm{~g}$; beef extract, $3 \mathrm{~g}$; agar, $15 \mathrm{~g}$; tyrosine, $5 \mathrm{~g}$; distilled water, $1,000 \mathrm{ml}$; pH 7.0. The medium was thoroughly mixed during each step in its preparation to provide a final, even distribution of the insoluble tyrosine throughout the agar.

Utilization of benzoate. The cultures were inoculated and incubated at $28 \mathrm{C}$ for 4 weeks on

1 This investigation was supported in part by a research grant, no. E 157-E $157\left(\mathrm{C}_{2}\right)$, from the National Institutes of Health, Public Health Service. the following medium, a modification of Koser's citrate agar (1924): $\mathrm{NaCl}, 1 \mathrm{~g} ; \mathrm{MgSO}_{4}, 0.2 \mathrm{~g}$; $\left(\mathrm{NH}_{4}\right)_{2} \mathrm{HPO}_{4}, 1 \mathrm{~g} ; \mathrm{KH}_{2} \mathrm{PO}_{4}, 0.5 \mathrm{~g} ; \mathrm{Na}$ benzoate, $2 \mathrm{~g}$; agar, $15 \mathrm{~g}$; distilled water, $1,000 \mathrm{ml}$. The $\mathrm{pH}$ of the agar was adjusted to 7.0 , and $20 \mathrm{ml}$ of a 0.04 per cent solution of phenol red were added. An alkaline reaction of the medium indicated use of the benzoate.

Acid from carbohydrates. Maltose and trehalose were used in conjunction with the carbohydrates previously listed.

\section{DESCRIPTIONS OF SPECIES}

The collection ${ }^{2}$ of mycobacteria forming the basis of this taxonomic study increased from the 124 strains of the first report to 195 . The named strains, as received, represented 23 different species; the unnamed ones were isolated from a variety of sources. Of the 195 strains, 68 per cent were assigned to the following three taxa:

\section{Mycobacterium phlei Lehmann and Neumann}

The six strains (three received as $M$. phlei and three unnamed isolations) added to the original 21 of this species (Gordon and Smith, 1953, p. 43) are listed in table 1 . General agreement on the identity of $M$. phlei was again evidenced by the correct identification of the three named strains and the absence of misnamed strains and of strains bearing specific names in synonymy.

Cultures of the six strains grown on glycerol agar for 5 days at $28 \mathrm{C}$ were 25 to 80 per cent acid fast. The cells varied from coccoid forms to short filaments, and some had granular protoplasm. The colonial morphology, macroscopic appearance, temperature relationships, and

2 The writers wish to express their sincere ap. preciation to the investigators who kindly sup. plied the cultures for this study. 
TABLE 1

Strains identified as Mycobacterium phlei Lehmann and Neumann

\begin{tabular}{|c|c|}
\hline $\begin{array}{c}\text { Laboratory } \\
\text { Number }\end{array}$ & Name and Source \\
\hline 464 & $\begin{array}{l}\text { Mycobacterium phlei Lehmann and } \\
\text { Neumann; W. Steenken, Jr., Tru- } \\
\text { deau Lab. }\end{array}$ \\
\hline 468 & $\begin{array}{l}\text { Mycobacterium phlei; G. Penso, Isti- } \\
\text { tuto Superiore de Sanita, Rome } \\
\text { (Timoteo } 2 \times \text { ) }\end{array}$ \\
\hline 500 & $\begin{array}{l}\text { Mycobacterium phlei; A. Abrams, } \\
\text { Army Med. Services Grad. School } \\
(52-\mathrm{R}-1)\end{array}$ \\
\hline 451 & $\begin{array}{l}\text { Mycobacterium sp; D. W. Bruner, Cor- } \\
\text { nell Univ. (57); C. A. Frey (soil) }\end{array}$ \\
\hline 479 & $\begin{array}{l}\text { Mycobacterium sp; P. Stuart, Minis- } \\
\text { try of Agr. and Fisheries, England } \\
\text { (MS. 247.52, bovine mastitis) }\end{array}$ \\
\hline 501 & $\begin{array}{l}\text { Mycobacterium sp; A. Abrams (52-B-1, } \\
\text { associated with leprous lesions) }\end{array}$ \\
\hline
\end{tabular}

other reactions agreed with those of the previously described strains of $M$. phlei. All grew from $28 \mathrm{C}$ to $52 \mathrm{C}$ inclusive; none, at $10 \mathrm{C}$; and all survived $60 \mathrm{C}$ for 4 hours. Only one culture (no. 451) hydrolyzed gelatin to a limited extent; none decomposed casein or grew in broth containing 5 per cent $\mathrm{NaCl}$. The six strains utilized citrate, succinate, and malate; reduced nitrate to nitrite; hydrolyzed starch; and formed acid from glucose, xylose, arabinose, mannose, galactose, mannitol, and sorbitol. Acid formation from rhamnose, inositol, dulcitol, lactose, and raffinose was negative.

The following reactions of the 27 strains in this collection identified as $M$. phlei were determined and used to supplement the description of the species:

Decomposition of tyrosine. All cultures were negative.

Utilization of benzoate. All cultures were negative.

Acid production from carbohydrates. Two cultures (nos. N8151 and M354) of the 27 were able to form acid from maltose; 18 formed acid from trehalose.

\section{Mycobacterium smegmatis (Trevisan) Lehmann and Neumann}

Eighteen of the 24 additional strains assigned to this species were unidentified isolations, and the remaining six were received as representatives of four different species (see table 2). Strain no. 465 of Mycobacterium butyricum and strain no. 446 of Mycobacterium friedmannii were in agreement with others bearing the same labels and previously assigned to the synonymy of $M$. smegmatis. The three strains received as Mycobacterium ranae also conformed to those examined earlier and were identical with strains

TABLE 2

Strains identified as Mycobacterium smegmatis (Trevisan) Lehmann and Neumann

\begin{tabular}{|c|c|}
\hline $\begin{array}{l}\text { Laboratory } \\
\text { Number }\end{array}$ & Name and Source \\
\hline 447 & $\begin{array}{l}\text { Mycobacterium aquae Maië; CCTM } \\
\text { (7) }\end{array}$ \\
\hline 465 & $\begin{array}{l}\text { Mycobacterium butyricum Bergey et } \\
\text { al.; W. Steenken, Jr., Trudeau } \\
\text { Lab. }\end{array}$ \\
\hline 446 & $\begin{array}{l}\text { Mycobacterium friedmannii Holland; } \\
\text { CCTM (178) }\end{array}$ \\
\hline 540 to 542 & $\begin{array}{l}\text { Mycobacterium ranae (Küster) Ber- } \\
\text { gey et al.; J. Hsie, Still College (1, } \\
\text { original wild type; } 2 \text {, isoniazid } \\
\text { resistant, slow growing; } 5 \text {, isonia- } \\
\text { zid resistant, fast growing) }\end{array}$ \\
\hline $108,114 \mathrm{M}$ & $\begin{array}{l}\text { Mycobacterium spp; E. B. McKin- } \\
\text { ley, George Washington Univ. }\end{array}$ \\
\hline 422 & $\begin{array}{l}\text { Mycobacterium sp; Isabel Christi- } \\
\text { son, Duke Univ. (317); D. K. } \\
\text { Miller }\end{array}$ \\
\hline 450 & $\begin{array}{l}\text { Mycobacterium sp; D. W. Bruner, } \\
\text { Cornell Univ. (50); C. A. Frey } \\
\text { (soil) }\end{array}$ \\
\hline 454 & $\begin{array}{l}\text { Mycobacterium sp; D. W. Bruner } \\
\text { (135); W. Willie (soil) }\end{array}$ \\
\hline 455 & $\begin{array}{l}\text { Mycobacterium sp; D. W. Bruner } \\
\text { (166); Ruth E. Gordon (soil) }\end{array}$ \\
\hline 470 to 472 & $\begin{array}{l}\text { Mycobacterium spp; P. Stuart, Min- } \\
\text { istry of Agr. and Fisheries, Eng- } \\
\text { land (MS.231.52“'S", MS.231.52 } \\
\text { "R", MS.104.51“S", bovine mas- } \\
\text { titis) (Stuart and Harvey, 1951) }\end{array}$ \\
\hline 474 & $\begin{array}{l}\text { Mycobacterium spp; P. Stuart (MS. } \\
302.51 \text { "S", MS.302.51“R", MS. } \\
\text { 48.52“S", MS.48.52“R", bovine } \\
\text { mastitis) }\end{array}$ \\
\hline 497,498 & $\begin{array}{l}\text { Mycobacterium spp; M. Panisset, } \\
\text { Univ. of Montreal (7A, 10A); G. } \\
\text { Penso }\end{array}$ \\
\hline 573,574 & $\begin{array}{l}\text { Mycobacterium spp; S. R. Kham- } \\
\text { bata, St. Xavier's College, India } \\
\left(\mathrm{O}_{11}, \mathrm{O}_{12} \text {, intestinal flora of earth- }\right. \\
\text { worm) }\end{array}$ \\
\hline 4242 & $\begin{array}{l}\text { Mycobacterium sp; ATCC; C. W. } \\
\text { Duval (Levy-Kedrowski 115, as- } \\
\text { sociated with leprous lesions) }\end{array}$ \\
\hline
\end{tabular}


of $M$. smegmatis. Because of their disagreement with the original account of $M$. ranae (Küster, 1905), they had to be regarded as misnamed.

Strain no. 447 was the first obtained under the name Mycobacterium aquae. Galli-Valerio (1912) mentioned acid fast organisms present in scrapings from water faucets but gave them no description or name. Later, Maië (1922) described an acid fast strain from the water pipes of Lausanne and referred to it as $M$. aquae GalliValerio. In spite of a careful search, no paper by Galli-Valerio naming and characterizing the species has been found to precede 1922 . It is tentatively assumed that Maië is the proper authority for the species and that he attributed the specific name to Galli-Valerio as a matter of courtesy. Maië's account and a later one by Galli-Valerio and Bournand (1927) were very general but did not prohibit the acceptance of strain no. 447 as authentic and the listing of $M$. aquae in the synonymy of $M$. smegmatis.

The microscopic aspect, acid fastness, colonial morphology, and macroscopic appearance of the 24 strains conformed to those of the other strains previously classified as $M$. smegmatis. The 24 strains grew from $28 \mathrm{C}$ to $45 \mathrm{C}$ inclusive; few grew at $10 \mathrm{C}$; none, at $52 \mathrm{C}$; and none survived 4 hours at $60 \mathrm{C}$. Two-thirds of the strains grew in 5 per cent $\mathrm{NaCl}$ broth. Gelatin and casein were not attacked; nitrates were reduced to nitrites by all strains; starch was hydrolyzed; citrate, succinate, and malate were utilized; acid was formed from glucose, rhamnose, xylose, arabinose, mannose, galactose, mannitol, ${ }^{3}$ sorbitol, inositol, and dulcitol. Lactose and raffinose were not used as sources of carbon.

The tests used to supplement the species' description of $M$. phlei were also applied to all the strains of $M$. smegmatis.

Decomposition of tyrosine. All cultures were negative.

Utilization of benzoate. All but four cultures (nos. 375 to 377,380 ) were positive.

Acid production from carbohydrates. Twentyfour per cent of the cultures formed acid from maltose; 100 per cent, from trehalose.

The addition of the foregoing characters to the species' description of $M$. smegmatis and a careful check of previous examinations resulted

3 Omitted by error from the previous list of carbohydrates hydrolyzed by $M$. smegmatis. in the separation from the species of two strains, nos. 283 and 4236 (Gordon and Smith, 1953, p. 45 ), previously assigned to $M$. smegmatis. Variation from the normal in one or two reactions of the species' pattern was considered of no taxonomic significance. Strains nos. 283 and 4236, however, differed in too many respects from the enlarged series of characteristics to be accepted as belonging to the species and were again placed with the unclassified strains of the collection. Except for a few, uncorrelated, minor variations, the remaining 54 strains previously identified as $M$. smegmatis and the 24 listed in table 2 conformed to the proposed species' description.

\section{Mycobacterium fortuitum Cruz}

The strains comprising the third taxon of rapidly growing acid fast bacteria were isolated from soil and from infections of humans, cattle, and cold-blooded animals (table 3 ). The oldest species represented in the group was designated Mycobacterium enteritidis, Lehmann and Neumann's name (1927) for the Johne's bacillus. On the basis of a single strain, no conclusion can be drawn on the relationship between the slowly growing, fastidious Johne's bacillus and these rapidly growing strains. For practical reasons alone, however, the application of a specific name in the synonymy of Mycobacterium paratuberculosis Bergey et al. to a species of the rapidly growing strains would not be feasible.

The next oldest species represented was labeled $M$. fortuitum and described by Cruz in 1938. This name is tentatively adopted for the species. It is difficult to believe, however, that such a widespread organism was not isolated and characterized long before 1938. Should an authentic strain bearing an earlier effectively published name (Buchanan et al., 1948) be found to belong to this species, the name now applied would have to be changed to the earlier one.

Under the conditions of this examination, strains of Mycobacterium giae Darzins (1950) and Mycobacterium minetti Penso et al. (1952) were identical with others of this taxon. Although some discrepancies existed between the original descriptions of the two species and the one given here, they were believed due to differences in methods. It is recommended, therefore, that $M$. giae and $M$. minetti be placed in the synonymy of $M$. fortuitum. The similarity between NCTC strain no. N946 of $M$. friedmannii Holland and 
those of $M$. fortuitum casts some doubt on the previous assignment of $M$. friedmannii to the synonymy of $M$. smegmatis. This assignment was made because ATCC and CCTM strains of $M$. friedmannii were identical with those of $M$. smegmatis, and Friedmann's original description (1903) was too general to establish definitely the identity of his strain. Friedmann's account could be applied to a strain of $M$. smegmatis or to a strain of $M$. fortuitum. Until more information can be obtained, it is suggested that $M$. friedmannii be left in the synonymy of $M$. smegmatis and NCTC strain no. N946 be regarded as possibly misnamed.

The following description of $M$. fortuitum was based on the 28 strains listed in table 3:

Microscopic appearance. Cells grown on glycerol agar for 72 hours at $28 \mathrm{C}$ varied from $1.0 \mu$ to $3.0 \mu$ in length, the largest number ranging from $2.0 \mu$ to $2.2 \mu$. After 5 days' incubation at $28 \mathrm{C}$ on glycerol agar, 70 to 100 per cent of the cells of 17 of the 28 cultures were acid fast; the remaining 9 cultures were 10 to 50 per cent acid fast. The cells varied from coccoid and short rods to long, slender rods, occasionally beaded or swollen by a nonacid fast, oval body at one end.

Colonial morphology was similar to that of M. phlei and $M$. smegmatis. After 3 or 4 days' incubation, dense colonies with smooth edges and dense colonies fringed with short filaments and/or filamentous colonies were observed. Upon further incubation the filaments usually fragmented into short rods.

Macroscopic appearance. Growth on glycerol agar after 2 or 3 days at $28 \mathrm{C}$ was scant to fair, soft and butyrous, or waxy and nodular, off-white to cream colored. After 2 weeks, growth of the cultures was good to abundant, spreading, butyrous and glistening or dull, rough, and waxy, often very nodular, off-white to cream to beige in color. On yeast extract agar growth was moderate to heavy, spreading, butyrous or dry and waxy, usually nodular, sometimes finely wrinkled, off-white to cream to beige. Growth on glucose-asparagine agar at 2 weeks was moderate, spreading, soft and glistening or dull and waxy, off-white to cream color.

Temperatures of growth. The 28 strains grew from $28 \mathrm{C}$ to $35 \mathrm{C}$; all but 6 (nos. 48, 448, 449, 9822, 11440, N946) grew at $40 \mathrm{C}$; and approxi-
TABLE 3

Strains identified as Mycobacterium fortuitum Cruz

\begin{tabular}{c|c}
\hline $\begin{array}{c}\text { Laboratory } \\
\text { Number }\end{array}$ & Name and Source \\
\cline { 2 - 2 } N6926 & $\begin{array}{c}\text { Mycobacterium enteritidis Lehmann } \\
\text { and Neumann; NCTC (5026) }\end{array}$
\end{tabular}

6841, 6842 Mycobacterium fortuitum Cruz; ATCC; J. C. Cruz (1, 2, human abscess)

N946 Mycobacterium friedmannii Holland; NCTC

11440 Mycobacterium giae Darzins; ATCC E. Darzins (systemic, nodular infection of gias)

480 Mycobacterium minetti Penso et al.; G. Penso, Istituto Superiore de Sanita, Rome (C70)

48 Mycobacterium sp; W. A. Hagan, Cornell Univ. (soil)

374 Mycobacterium sp; J. BentinckSmith, Cornell Univ.; E. W. Tucker (bovine mastitis)

389 Mycobacterium sp; G. Alexander, Rutgers Univ. (B8, barnyard soil)

394, 395 Mycobacterium spp; W. A. Hagan (52-80, 52-79); P. Stuart (MS. 197.51, MS.144.51, bovine mastitis)

448, 490 Mycobacterium spp; CCTM (Karlinski 58, sable 73)

449 Mycobacterium sp; D. W. Bruner, Cornell Univ. (48, soil)

456 to 461 Mycobacterium spp; E. W. Tucker, Cornell Univ. (1595, 84/2 cow $1705,21 / 2$ cow $155,89 / 3$ cow 1351 , $72 / 2$ cow $1555,76 / 3$ cow 1422 bovine mastitis) (Tucker, 1953)

9820 Mycobacterium sp; ATCC; NCTC (2014); Král Collection (fish)

9821 Mycobacterium sp; ATCC; NCTC (2291); A. S. Griffith (roe of halibut)

9822 Mycobacterium sp; ATCC; NCTC (2006); G. S. Wilson (terrapin)

N2291 Mycobacterium sp; NCTC (halibut)

N3630 Mycobacterium sp; NCTC (Cummin's M bacillus)

N8573 Mycobacterium sp; NCTC; E. Aguis (Malta, cervical adenitis)

N8697 Mycobacterium sp; NCTC (human abscess)

435 Nocardia sp; Isabel Christison, Duke Univ. (2229); N. F. Conant; E. Palik (sputum) 
mately one-half grew at $10 \mathrm{C}$. Growth, if any, was very scant at $45 \mathrm{C}$.

Survival of $60 \mathrm{C}$. None of the cultures grew after 4 hours in the water bath at $60 \mathrm{C}$.

Hydrolysis of starch. All cultures were positive.

Acid production from carbohydrates. All cultures formed acid from glucose, mannose, and trehalose; a few (nos. 48, 449, 490, 11440, N2291) utilized mannitol. Acid production from rhamnose, xylose, arabinose, galactose, sorbitol, inositol, dulcitol, lactose, and raffinose was negative; with one exception (no. 9822), maltose was not hydrolyzed.

Hydrolysis of gelatin. All cultures were negative.

TABLE 4

Comparison of reactions of three species of Mycobacterium

\begin{tabular}{|c|c|c|c|}
\hline \multirow{2}{*}{ Reactions } & \multicolumn{3}{|c|}{ Mycobacterium } \\
\hline & phlei & smesmatis & fortwilum \\
\hline \multicolumn{4}{|l|}{ Decomposition of : } \\
\hline gelatin & $\mp^{*}$ & - & - \\
\hline casein & - & - & - \\
\hline tyrosine & - & - & - \\
\hline \multicolumn{4}{|l|}{ Growth at: } \\
\hline $52 \mathrm{C}$ & + & - & - \\
\hline $45 \mathrm{C}$ & + & + & - \\
\hline $40 \mathrm{C}$ & + & + & $\pm \dagger$ \\
\hline Survival $60 \mathrm{C}, 4 \mathrm{hr}$ & + & - & - \\
\hline Nitrite from nitrate & + & + & + \\
\hline \multicolumn{4}{|l|}{ Utilization of : } \\
\hline citrate & + & + & + \\
\hline succinate & + & + & + \\
\hline malate & + & + & + \\
\hline benzoate & - & + & - \\
\hline Hydrolysis of starch & + & + & + \\
\hline \multicolumn{4}{|l|}{ Acid from: } \\
\hline glucose & + & + & + \\
\hline rhamnose & - & + & - \\
\hline xylose & \pm & + & - \\
\hline arabinose & + & + & - \\
\hline mannose & + & + & + \\
\hline galactose & \pm & + & - \\
\hline mannitol & + & + & $\mp$ \\
\hline sorbitol & + & + & - \\
\hline inositol & - & + & - \\
\hline dulcitol & - & + & - \\
\hline lactose & - & - & - \\
\hline raffinose & - & - & - \\
\hline maltose & - & $\mp$ & - \\
\hline trehalose & \pm & + & + \\
\hline
\end{tabular}

* Majority of strains negative.

$\dagger$ Majority of strains positive.
Hydrolysis of casein. All cultures were negative. Utilization of citrate, succinate, and malate. Only one culture (no. 395) failed to utilize citrate; all utilized succinate and malate.

Reduction of nitrate to nitrite. All but four cultures (nos. 395, 448, 9822, N946) reduced nitrate to nitrite.

$\mathrm{NaCl}$ tolerance. Growth, if any, was very scant in 7 per cent $\mathrm{NaCl}$ and usually positive in 5 per cent.

Decomposition of tyrosine. All cultures were negative.

Utilization of benzoate. All cultures were negative.

Portions of the descriptions of $M$. phlei, $M$. smegmatis, and $M$. fortuitum are arranged for comparative purposes in table 4. Maximum temperatures of growth, survival of $60 \mathrm{C}$, utilization of benzoate, and acid production from rhamnose, xylose, arabinose, galactose, sorbitol, inositol, and dulcitol provided combinations of reactions separating the three species one from the other. Although the other reactions listed in table 4 did not differentiate the three species, they were, on the whole, stable and of value in the recognition of the three species. Some of them also gave promise of usefulness in the delineation of the other species, at present partially represented by the remaining 32 per cent of the 195 strains in this collection.

\section{SOMMARY}

The collection of rapidly growing, acid fast bacteria was increased from 124 to 195 by the examination of 71 more strains. The new strains, identified as Mycobacterium phlei Lehmann and Neumann and Mycobacterium smegmatis (Trevisan) Lehmann and Neumann, were listed and a few supplementary characters were added to the descriptions of these two species.

A third species, Mycobacterium fortuitum Cruz, was characterized and compared with $M$. phlei and $M$. smegmatis. Mycobacterium giae Darzins and Mycobacterium minetti Penso et al. were listed in the synonymy of $M$. fortuitum.

\section{REFERENCES}

Buchanan, R. E., St. John-Brooks, R., AND BREED, R. S. 1948 International bacteriological code of nomenclature. J. Bacteriol., 55, 287-306.

Cruz, J. C. 1938 Mycobacterium fortuitum um 
novo bacilo acido-resistente patogenico para o homen. Acta Med. Rio de Janeiro, 1, 297301.

Darzins, E. 1950 Tuberculose das gias (Leptodactylus pentadactylus). Arquiv. inst. brasil. Invest. Tuberc., 9, 29-37.

Friedmann, F. F. 1903 Der Schildkrötentuberkelbacillus, seine Züchtung, Biologie, und Pathogenetät. Zentr. Bakteriol., Parasitenk., Orig., I, 34, 647-658.

Galli-Valerio, B. 1912 Etudes sur les actinomycètes. Zentr. Bakteriol., Parasitenk., Orig., I, 63, 554-564.

Galli-Valerio, B., and Bournand, M. 1927 Le Mycobacterium aquae Galli-Valerio et son action pathogene. Zentr. Bakteriol., Parasitenk., Orig., I, 101, 182-193.

Gordon, R. E., AND SMrTH, M. M. 1953 Rapidly growing, acid fast bacteria. I. Species' descriptions of Mycobacterium phlei Lehmann and Neumann and Mycobacterium smegmatis (Trevisan) Lehmann and Neumann. J. Bacteriol., 66, 41-48.

Koser, S. A. 1924 Correlation of citrate utilization by members of the colon-aerogenes groups with other differential characteristics and with habitat. J. Bacteriol., 9, 59-77.

KÜster, E. 1905 Ueber Kaltblütertuberkulose. Münch. med. Wochschr., 62, 57-59.

LehmanN, K. B., and Neumann, R. O. 1927 Bakteriologische Diagnostik. J. F. Lehmanns Verlg./München, 7. Auf., II. Band, 755-756.

MarË, S. 1922 Experimentelle Versuche bei Goldfischen (Carassius auratus) mit säurefesten Bazillen. Zentr. Bakteriol., Parasitenk., Orig., I, 88, 28-38.

Penso, G., Castelnuovo, G., Gaudiano, A., Princivalle, M., Vella, L., and Zampieri, A. 1952 Studi e ricerche sui micobatteri. VIII. Un nuovo bacillo tubercolare: il Mycobacterium minetti n. sp. Studio microbiologico e patogenetico. Rend. ist. super. sanita, 16, 491-538.

Stuart, P., and Harvex, P. 1951 Bovine mastitis resembling tuberculosis caused by $M y$ cobacterium lacticola and other rapidly growing acid-fast bacteria. Vet. Record, 63, 1-4.

TUCKER, E. W. 1953 Infection of the bovine udder with Mycobacterium spp. Cornell Vet., 43, 576-599. 